\title{
„JSEM RÁD, ŽE NOTY BUDOU V POŘÁDKU.“ LEOŠ JANÁČEK A BŘETISLAV BAKALA - VZÁJEMNÝ VZTAH DVOU UMĚLCŮ
}

Břetislav Bakala (1897-1958) byl oddaný Janáčkův žák, který se zhlédl v jeho tvorbě už od počátku svých studií na varhanické škole v Brně (1912-1915). Značně se zasloužil o šiŕrení Janáčkova díla, z něhož nemalou část nahrál na gramofonové desky (Hradčanské pisničky; Vlči stopa; Kašpar Rucký; Řikadla; Glagolská mše; Šárka; Kát’a Kabanová; Věc Makropulos; Osud ${ }^{1}$ - Duet Míly a Živného z prvního dějství, Ty naše zlaté sluničko; Přihody lišky Bystroušky - Sbor lištiček a závěr; Capriccio; Concertino; Moravské tance; Lašské tance; Taras Bulba; Symfonietta), pořizoval klavírní výtahy Janáčkových děl (Kát’a Kabanová; Přihody lišky Bystroušky; Mládi; Taras Bulba; Z mrtvého domu; Na Soláni čarták; Věčné evangelium; předehra k Šárce), poprvé provedl Zápisník zmizelého (18. 4. 1921, Brno, Reduta, 18. 10. 1921, Praha, Mozarteum, Břetislav Bakala - klavír), Suitu, op. 3 (23. 9. 1928, Brno, Výstava současné hudební kultury 1928, pražský a brněnský rozhlasový orchestr), v roce 1930 dirigoval premiéru opery $Z$ mrtvého domu (12. 4. 1930, Brno, Národní divadlo), smíšený sbor Naši píseň (11. 12. 1930, Brno, brněnský rozhlasový sbor), Elegii na smrt dcery Olgy a Adagio pro orchestr (20. 12. 1930, Brněnský rozhlasový orchestr). O čtyři roky později řídil v rozhlase první provedení opery Osud (13. 3. 1934 - první a třetí dějství; 2. 7.1934 - druhé dějství; 18. 9. 1934 - celá opera) a v roce 1948 premiéru symfonické básně Dunaj (2. 5. 1948, Brno, Symfonický orchestr brněnského rozhlasu). Taktéž zrevidoval Baladu blanickou a Suitu, op. 3 (vydalo Státní nakladatelství krásné literatury, hudby a umění 1958, dále jen SNKLHU). V popředí všeho tedy stojí Bakala jako dirigent a interpret Janáčkových děl.

\section{Studia u Janáčka}

„Poprvé jsem se setkal s Leošem Janáčkem jako tercián brněnského gymnasia. Tehdy mne poslal profesor zpěvu František Dvořáček, abych zpival ve sboru v kantátě Nowowiejského ,Quo vadis', kterou Janáček zrovna pripravoval

1 Gramofonová deska nevyšla. Český rozhlas Brno má pouze trvalý záznam na pásce. 
na varhanické škole. Pak jsem ho často potkával na procházce, jak kráčel zvolna kolébavým krokem, pohazoval si hůlčičkou. Byl jsem štasten, když na můj uctivý pozdrav odpověděl svým krátkým ,Ja, dobrýden!"

Do stálého, bližšiho styku s ním jsem přišel v roce 1912 na varhanické škole. Do té doby jsem znal jen některé Janáčkovy sbory, později klavírni cyklus ,V mlhách ', hraný na ústavním večirku, a Pastorkyňu, provedenou ve Starém divadle. “2

Tak začínají Bakalovy vzpomínky nazvané $Z$ mého hudebního života, napsané kolem roku 1956. Jsou krátké, rozsahem asi jen šest stran strojopisu. Bakala se v nich hned od začátku zaměřuje na vše, co bylo v jeho životě spojeno s Leošem Janáčkem - na dobu svých studií u Janáčka a na vliv velkého učitele na budoucího skladatele a dirigenta. Bakala byl zřejmě Janáčkovou osobností uchvácen do té míry, že nastoupil na varhanickou školu, kterou absolvoval s vyznamenáním v letech 1912-1915. Obdiv k Janáčkovi zůstal Bakalovi i po vojenské službě v Jugoslávii za první světové války a vyburcoval ho po př́ijezdu domů k nesnadnému návratu $\mathrm{k}$ náročnému studiu. Bakala se roku 1919 zapsal na brněnskou konzervatoř a její mistrovskou skladatelskou školu a opět se tak stal žákem Leoše Janáčka, tentokrát v oboru skladba. Ten mu o rok později vystavil dokument, svědčící o jeho schopnostech:

„Stvrzuji, že p. Břetislav Bakala je v mistrovské škole skladby hudebni; je oprávněna naděje, že při jeho vzorné pilnosti, snaze a opravdovém nadání, $v$ tomto oboru dospěje výsledků velmi dobrých. Brno, 8. března 1920."3

Janáček musel už tehdy ve svém žákovi vidět jeho hudební nadání a vkládal do něj zřejmě velké naděje. Bakala byl neobyčejně pilný student, kromě studia kompozice u Janáčka patřil do třídy dirigování Františka Neumanna (18741929), navštěvoval soukromé hodiny klavíru u Viléma Kurze (1872-1945), sledoval též brněnskou hudební kulturu, kterou se snažil i přses ne vždy prríznivé finanční okolnosti hojně navštěvovat, ve svém studiu byl neobyčejně poctivý, vždy dbal na progresivní uměleckou orientaci. O tom, že se chtěl na svoje budoucí postavení ve světě hudby dokonale připravit, svědčí i druhý dokument podepsaný Leošem Janáčkem:

„Prospěch vynikajicí. Pan Břetislav Bakala vyzná se výborně v psychologickém průběhu skladebném, v rozpoznání podstaty formační a architektonické hudebniho díla, v primitivismu skladebném lidové pisně, tak $i$ ve směrech vývojného soudobého skládání. Praha, 28. června 1923.“4

První dokument vystavil Janáček Bakalovi jako doporučení pro jeho prijetí do Národního divadla v Brně, kam Bakala nastoupil jako korepetitor a kapelník v roce 1920. Druhý dokument sloužil jako diplom mistrovské školy Státní konzervatoř hudby v Praze, kde byl Janáček profesorem.

2 ŠTĚDROŇ, Bohumír. Břetislav Bakala, člověk a umělec. In Státni filharmonie Brno 19561966. Brno: Blok, 1964, s. 10-15.

3 Dopis je uložen v Janáčkově archivu Moravského zemského muzea v Brně (dále jen JA MZM), sign. D 1800.

4 ŠTĚDROŇ, op. cit., s. 16. 
Bakalovým absolutoriem v oboru skladba sice skončila jeho studia u Leoše Janáčka, nikoli však jejich vzájemná spolupráce. Janáčkovi zůstal Bakala věrný po celý svůj život.

\section{Bakala - tvůrce klavírních výtahů}

Ve svých dopisech Janáčkovi se Bakala často zmiňuje o rozdělané práci na klavírním výtahu některého z Mistrových děl. Sám Janáček pověřoval svého žáka tímto odpovědným úkolem a často se ho ve své korespondenci dotazoval, jak práce postupuje, či zdali je už s dílem hotov. Právě vzájemná korespondence mezi Janáčkem a Bakalou je jediným zdrojem informací o postupu při práci na klavírních výtazích.

První klavírní výtah, který Bakala vypracoval, se týkal Janáčkovy v pořadí šesté opery Káta Kabanová (klavírní výtah vydala Univerzální edice roku 1922). Janáček původně žádal o vypracování klavírního výtahu Romana Veselého (1879-1933), ale ten tuto práci odmítl, skladatel se tedy obrátil na Břetislava Bakalu. Právě o Káti Kabanové proběhla v Janáčkově a Bakalově korespondenci žrejmě nejživější diskuse, z níž jsou vybrány následující úryvky. Dopis psaný Bakalou v Brně 24. 8. 1921:

„Drahý Mistře!

Dnes jsem dostal od Nešuty II. akt. Chyb tam nadělal dost! Tak to ještě zitra opravím a dám hned do divadla. Do tiskárny pošleme ten mưj výtah, protože Svozil o tom mluvil se šéfem, který prý se vyjádřil, že my musíme mít ten čistý výtah, jelikož začneme Kát’u hned po Faustu studovat, a nebudeme čekat na tištěné výtahy. Ale bylo by snad dobře, kdybyste, Mistře, sám do Universálni edice napsal, aby si s tiskem pospišili a poslali nám aspoň nějaký kartáčový otisk. Čítám totiž s premiérou nejpozději počátkem listopadu, myslím však, že bude asi v druhé polovici řijna. Po Figarově svatbě, která je stanovena na 20. ř́̉jna, se pustíme do studia plnou parou. [...] Prosím tedy o sdělení, kam mám poslat ten klavírní výtah; zda do Univ. edice, nebo panu [?] Brodovi."5

Načež Janáček obratem odpovídá dopisem z 25. 8. 1921 z rodných Hukvald:

„Milý príteli!

Jsem rád, že noty budou v pořádku. P. chefa Neumanna žádám, aby se cvičilo $z$ Vašeho rukopisu klavírního výtahu. Opsaný p. Nešutou bude jistě čistší; z Vašeho nebylo by možné tisknout - když by se tisklo v Lipsku. Neprečetli by text! Muselo by se to ještě prepisovat. Tisk by nebyl do premiery hotov.

Přhlédněte bedlivě $p$. Nešutiov opis a pošlete ho hned recom. na adresu

Dr. Max Brod

spisovatel

Praha

Břehová 8."6

5 Dopis je uložen v JA MZM, sign. A 967.

6 Dopis je uložen v JA MZM, sign. A 7344. 
Jak je z doložené korespondence patrné, nebylo vždy vypracování a vydání klavírních výtahů bez problémů. $\mathrm{K}$ jejich rychlému řešení však přispíval velmi dobrý vztah obou umělců, kteří se nemuseli ostýchat sdělit druhé straně vše narovinu, aniž by se obávali sebemenšího nepochopení. V tomto ohledu měl Janáček jako skladatel v Bakalovi věrného žáka a obdivovatele, na kterého se mohl vždy obrátit a plně spolehnout.

Hned za Kátou Kabanovou následovala práce na Janáčkově sedmé opeře Př́hody lišky Bystroušky (klavírní výtah vydala Univerzální edice v roce 1924). Také $\mathrm{v}$ tomto př́ípadě nacházíme ve vzájemné korespondenci obou zúčastněných dialog nad klavírním výtahem. Dokladem toho jsou především dva následující dopisy, první adresován Janáčkovi z Brna 23. 8. 1923:

„Drahý mistře,

[...] Mohu Vám již skoro určitě sděliti, že budu do Vašeho prríjezdu s II. jednáním hotov; jsem totiž už ve 2. polovici. [...] Dále mi řekl chef, abych nechal I. jednáni Bystroušky už opsat. Budete tam ještě něco měnit, nebo mám to dát Kulhánkovi? Nebo čekat do Vašeho př́jezdu? [...]"

Druhý dopis je Janáčkovou okamžitou odpovédí z pobytu v Luhačovicích ze dne 24. 8. 1923:

„[...] Príijedu v neděli, 2. záři odpoledne. I. jednání klavirního výtahu nedávejte p. Kulhánkovi. Má s partiturou a hlasy co dělat [...]."

Více Janáček k Bakalově otázce stran klavírního výtahu nenapsal. Vše ostatní si řekli zřejmě až v Brně po Janáčkově př́ijezdu.

Na počátku roku 1925 vyšel v Praze v Hudební Matici Umělecké Besedy klavírní výtah Janáčkova komorního díla pro dechové sexteto Mládí(1924), o pět let později, roku 1930, vydala Univerzální edice klavírní výtah poslední Janáčkovy opery Z mrtvého domu, následovala kantáta Na Soláni čarták (SNKLHU, 1958) a již posmrtně vydaný klavírní výtah Věčného evangelia (SNKLHU, 1959).

Janáček žádal svého žáka též o vypracování klavírního výtahu předehry ke své operní prvotině Šárka a následné sjednocení s celou partiturou opery, ale jak dosvědčuje Bakalův dopis z 27. ř́jna 1925 zaslaný z Philadelphie, tato práce nebyla tehdy bohužel dokončena:

„[...] Co je s ,Śárkou'? Už se studuje? Nezlobte se, prosím Vás, že jsem nemohl už klav. výtah dokončit. Měl jsem před odjezdem tolik práce, že to při nejlepši vưli nešlo $[\ldots]$. . ${ }^{\text {9 }}$

Bakala se však zřejmě k této práci ještě vrátil, nebot' klavírní výtah předehry, který byl později vytvořen, je s největší pravděpodobností jeho dílem.

\footnotetext{
7 Dopis je uložen v JA MZM, sign. B 481.

8 Dopis je uložen v JA MZM, sign. A 7346.

9 Dopis je uložen v JA MZM, sign. B 1020.
} 


\section{Bakala - janáčkovský interpret}

Janáčkovská interpretace je jednou z nejdůležitějších otázek Bakalova uměleckého života. Zájem o Janáčka a jeho hudbu neprosazoval Bakala na úkor dalších skladatelů či mladé generace hudebníků, vždy se snažil pojímat celou hudební produkci tak, jak sama vyrůstala a utvářela se. Velmi se též zajímal o dílo Vítězslava Nováka, svého pozdějš́ího uměleckého i osobního př́tele, i tvorbu Josefa Suka. Tuto náklonnost k Novákovi a Sukovi dokázal obdivuhodně spojit s oddanou službou Leoši Janáčkovi.

Dř́ve, než nastoupil na brněnskou varhanickou školu, znal Bakala jen několik Janáčkových skladeb. Při svých studiích však přišel s Janáčkem do užšího styku, a jak sám popsal, vnikl do struktury hudby svého učitele velmi snadno a rychle: „Vycitil jsem již jako žák a prostý posluchač genialitu jeho hudby. Neshledával jsem ji tak komplikovanou, jak se zdála. Porozuměl jsem jí hned - bez jakéhokoli mudrování. Janáčkưv sloh se mi jevil jasným, jeho mozaiková práce, vázaná tempovou a rytmickou jednotou - průzračná, plynulá a logická. Nevadilo mi, že skladby postrádaji monumentální stavby a gradaci, jakou jsem obdivoval napríklad u Vitězslava Nováka. Uchvátil mne vždy silný, zvláštní motiv, podložený sice prostým akordem, ale nevšedním spojem. Uchvátil mne vždy živelný rytmus, spojujicí všecky, na první pohled libovolně priřrazené částečky v logický celek, a zcela přsné metrické vlnění, usměrňujicí celou větu pravidelným tepem srdce. Zaujaly mne Janáčkovy nenapodobitelné lyrické scény svou vroucností - a naopak, silně dramatické pasáže svou drtivou osudovostí. A přitom vše dosaženo tak prostými, jednoduchými prostředky! Ale především mne uchvátila pravdivost a životnost jeho výrazu."

Stejně tak byl svědkem přímé Janáčkovy práce, která ho vedla i k jeho dramaturgickému plánu:

„Měl jsem často príležitost poznat celé Janáčkovo dílo takřka při jeho zrodu, $v$ soukromí, pak při studiu $v$ divadle nebo orchestru a nakonec při mnoha provedeních. Byl jsem často svědkem jeho spokojenosti i nespokojenosti, jeho poznámek a oprav. Při každém novém nastudování doplňoval partituru častými zásahy a nápady, $k$ nevelké radosti divadelního archiváre, který téměř po každé zkoušce musel $v$ orchestrálnich partech přepisovat, škrabat a přelepovat. Poznal jsem ze zkušenosti, že při dobrém provedeni je obecenstvo Janáčkovou hudbou nadšeno$i$ když se zdá prostému posluchači z počátku obtižná a těžko srozumitelná. A proto jsem se už více než před pětadvaceti lety soustředil na reprodukci Janáčkovy hudby, která také zásluhou rozhlasu konečně bude mít takové misto, jaké ji náleží. "'10

Zde Bakala výstižně formuloval východisko svého zájmu o dílo Leoše Janáčka i základ interpretační. Jeho janáčkovství však nevycházelo jen z mocného zaujetí dílem svého učitele, který se naprosto vymykal veškerému konzervativnímu skladebnému stylu. Byla zde i Bakalova orientace na soudobou hudbu, ve které měl 
značný rozhled a která vyrůstala ze studia kompozice a praktické skladatelské činnosti $v$ době umělcova mládí.

Již za svého pobytu v Americe, kdy měl možnost potkat se se světovými umělci a slyšet jejich tvorbu, si zřejmě uvědomil velikost a světovost hudby Leoše Janáčka. I za svého pobytu ve Philadelphii zkoumal místní hudební prostředí $\mathrm{s}$ cílem uvést alespoň některá díla z Janáčkovy tvorby. Dokladem toho je několik dopisů, které poslal Janáčkovi z USA do Brna. Hned ve druhém dopise psaném 27. 10. 1925 z Philadelphie se projevuje Bakalovo nadšení a zájem o prosazení Janáčkova díla:

„[...] Zdejšsi orchestr čitá asi 115 členů, vesměs znamenitých hráču. Slyšel jsem už 3 koncerty. Mají báječné dřevěné nástroje a smyčce. Myslel jsem si hned na ,Taras Bulbu ', jak by asi zněl v tom obsazení 18 primů, 16 sekundů, 14 viol, 12 cell a 10 kontrabasů! To by bylo ohromné!

Mluvili jsme také s hobojistou, který je prímo jedinečný, o Vašem sextettu, Mládi'; psal jsem už domĩ, aby mi poslali partiturku, a kdyby snad vyšly už hlasy, mohl byste mi je nechat poslat. Myslím, že bychom to zde prosadili. [...]“11

Dne 5. 2. 1926 píše Janáčkovi z New Yorku další dopis, dokládající jeho hluboký zájem o Janáčkovu tvorbu:

„Přijel jsem si poslechnout Toscaniniho, Klemperera a Kusevického. Dnes jsem slyšel v Metropolitan opeře Toscu a konstatoval jsem, že pro takové obecenstvo ,Pastorkyňa ' rozhodně není. [...]"12

Janáčkovo dílo bylo Bakalovi zřejmě blízké také proto, že pramenilo z moravské lidové hudebnosti, s níž byl od dětství spojen, ale patrně i z podobnosti osudu učitele a žáka - Bakala stejně jako Janáček pocházel z rodiny s kantorskou tradicí, vyrůstal mezi více sourozenci a do Brna prrišel sotva dvanáctiletý - zvláštní podobnost životního osudu s Janáčkem, z níž však nemůžeme vyvozovat závěry, nýbrž se pouze domýšlet možných důvodů Bakalovy interpretační orientace.

\section{Bakalovo pojetí operních děl Leoše Janáčka}

Více než deset let působil Břetislav Bakala jako dirigent a šéf orchestru brněnského rozhlasu, ve kterém velmi rád uváděl Janáčkovy operní skladby, jejichž způsob interpretace však nejednou vyvolal polemiku. Janáček bohužel nebyl většinu svého života široce uznávaným skladatelem, v pražských hudebních kruzích ho považovali spiše za experimentátora a jeho díla nebyla vždy přijata $\mathrm{k}$ uvedení bez otázek a bez průtahů. Nadto se stávalo, že po přijetí díla vyvstaly při nastudování takové problémy, že patřičná skladba musela být autorovi vrácena. Problematika přijetí děl byla zrrejmě i jedním z důvodů, proč byl Janáček shovívavý $\mathrm{k}$ takovým pojetím své tvorby, jež se vždy plně neztotožňovala s jeho představami nebo původním záměrem.

11 Dopis je uložen v JA MZM, sign. B 1020.

12 Dopis je uložen v JA MZM, sign. A 3024. 
Po sedmatřiceti letech od jevištního uvedení premiéry Počátku románu uvedl Bakala tuto operu též v rozhlase (1931), k Janáčkovým nedožitým osmdesátinám v roce 1934 připravil pro rozhlas první provedení opery Osud a nezapomněl ani na Výlety páně Broučkovy $(1936,1947)$ či na Janáčkovu operní prvotinu Šárka, která měla několik repríz (rozhlasová premiéra 7. 4. 1937, další provedení roku 1939 a 1953).

Velmi blízký vztah měl Bakala k dramatu Její pastorkyňa, které studoval do nejmenších podrobností. Jenůfu řídil nap̌r. při zájezdu brněnského Národního divadla do Zlína v roce 1925, o tři roky později zaskočil bez př́pravy za onemocnělého Františka Neumanna v brněnském divadle, sám ji nastudoval roku 1941 pro rozhlasové uvedení. Dílo tehdy nezaznělo celé, zato byl výběr uveden v původním znění i s předehrou Žárlivost, která se při jevištním ani žádném jiném úplném uvedení opery nikdy nehrála a nehraje se ani dnes. Jak známo, uváděla se Jeji pastorkyňa po své pražské premiéře s retušemi Karla Kovařovice, které měly usnadnit její přijetí u tehdejšího publika. Bakala však studoval genezi díla a srovnával i jeho nerealizované verze, čímž prokázal životaschopnost Janáčkovy nejznámější opery i bez oprav a v původním syrovém znění. Nicméně neprosazoval tuto původnost a zastával zrejmě v polemice autentičnosti interpretace střední proud - tedy, že jsou úpravy oprávněné, jestliže jsou ku prospěchu díla.

Největši polemiku ale vyvolala Bakalova a Chlubnova reprodukce opery $Z$ mrtvého domu. Velmi kriticky se k ní vyjadřuje František Pala ve své studii Jevištni dílo Leoše Janáčka: „Ačkoliv všechny Bakalovy retuše byly motivovány touhou prospèt Janáčkovu dilu, a to tím více, že šlo o premiéru posmrtnou, nelze je nekriticky přijmout jako zlepšeni, tj. dotvořeni toho, co spěchajícimu mistrovi zůstalo jakoby mezi řádky. Neubližíme nijak Bakalovu jménu, nazveme-li je (po dvaceti pěti letech) z většiny spornými anebo zcela zbytečnými. “13

Tyto zásahy do Janáčkovy partitury odmítali svého času i jiní vykladači Janáčkova díla, ale není úkolem této studie o nich rozsáhleji pojednávat. Stručně jen pro orientaci uved'me, že retuše byly provedeny především v oblasti instrumentace a libreta, nejvíce byl však upraven závěr opery. Bakalův postup lze však odůvodnit z hlediska historického - podobně jako dnes, tak i v době Bakalově, určoval podobu interpretace dobový vkus. Nelze se tedy divit oslavnému konci opery, který byl sice zcela změněn oproti Janáčkově i Dostojevského verzi, ale zcela naplnil představy obecenstva dvacátých a třicátých let minulého století, které mělo za sebou první světovou válku a veškeré její hrůzy.

Dnešní praxe se naštěstí pomalu vrací $\mathrm{k}$ původní verzi, a to především $\mathrm{v}$ nejvíce poznamenaném závěru díla. Zůstala Bakalova instrumentace a jiné menší změny, které však již nezasahují do struktury díla tak závažně a nemají tedy podstatnější charakter.

13 PALA, František. Jevištní dilo Leoše Janáčka. In Musikologie 3, Praha - Brno: Melantrich - Pazdírek 1955, s. 61-210. Zde kapitoly Z mrtvého domu na s. 177-191; Úprava opery Z mrtvého domu, s. 191-207. 
O správnosti či nesprávnosti Bakalových retuší byly napsány četné kapitoly a články a vedly se nekonečné polemiky. Avšak ze všech diskusí, které se o Bakalových zásazích do Janáčkových děl vedly, vyplývá, že měly původ spíše v Bakalově umělecké povaze, než v naprostém ztotožnění s Janáčkovou osobností. At' už náš postoj k těmto úpravám bude jakýkoli, provždy zůstane Bakalova interpretace základním výkladem Janáčkových děl.

Libuše Janáčková je studentkou doktorského studijního programu v oboru Hudební věda na FF MU v Brně a kurátorkou janáčkovských sbírek Moravského zemského muzea. Základ této studie tvoří kapitoly z bakalářské diplomové práce obhájené na Ústavu hudební vědy FF MU v roce 2007.

\begin{abstract}
:
The study aims at some aspects of Břetislav Bakala's relationship to Leoš Janáček and his compositions. The article describes Bakala's studies at Janáček's organ school and master school of composition and presents Bakala's interpretation of his teacher's works and their propagation. Bakala is most distinguished in this respect since he pioneered performances of many Janáček's works and helped their establishment. He didn't prefer only large dramatic works but was willing to bring to life less known chamber and vocal works as well. Other Bakala's activities connected with Janáček are also presented - he was the author of piano-vocal scores, in the Brno Radio he recorded Janáček's compositions and as a pianist he performed chamber-vocal work The Diary of One Who Disappeared for the first time. Bakala was also an important contact between Janáček and the then director of the Brno Opera František Neumann.
\end{abstract}

\title{
Key words:
}

Břetislav Bakala, Leoš Janáček, studies with Janáček, interpretation of works, piano-vocal scores, Czechoslovak Radio - Radiojournal

\section{Bibliography:}

PALA, František. Jevištní dílo Leoše Janáčka. In Musikologie 3, Praha - Brno: Melantrich - Pazdírek 1955, s. 61-210.

PEČMAN, Rudolf. Apoteóza Břetislava Bakaly. Opus musicum, 1977, roč. 9, s. 12-34.

ŠTĚDROŇ, Bohumír. Břetislav Bakala, člověk a umělec. In Státní filharmonie Brno 1956-1966.

Brno: Blok, 1964, s. 10-15. 